\title{
Effect of Therapeutic Dietary Regimen on Wound Healing For Patients with Moderate Degree Burn
}

\author{
Wafaa Hassan Ali Awad Assistant lecturer ${ }^{1}$, Sanaa Mohamed Alaa El-deen \\ Professor $^{2}$, AmnayehyiaSaad Assistant professor $^{3}$, IhabZakyAzzam ${ }^{4}$, \\ Rana Hassan Emara ${ }^{5}$ \\ ${ }^{1,2,3}$ Medical-Surgical Nursing, Faculty of nursing, Alexandria University \\ ${ }^{4}$ Lecturer of Plastic and reconstructive surgeryGeneral Surgery Department, Faculty of Medicine, Alexandria \\ University \\ ${ }^{5}$ lecturer of nutrition Nutrition department, High Institute of public health, Alexandria University
}

\begin{abstract}
Burn patients develop patho-physiological alterations, which include extensive nitrogen loss, malnutrition, markedly increased metabolic rate and immunologic deficiency. The degree of increase in metabolic rate appears to be directly proportional to the extent of burn injury. As a result of accelerated patients' metabolism the increased requirements for macronutrients as carbohydrates, proteins, fats and Micronutrients as vitamins, minerals, and antioxidants. The study aimed to determine the effect of therapeutic dietary regimen on wound healing for patients with moderate degree burn. It was carried out at the burn of Main University hospital, from 2014 till 2016. A sample included 66 adult recent moderately burned patients assigned sequentially into a group I $(n=33)$ who receive routine hospital diet, and group II $(n=33)$ who receive high caloric and protein diet from natural sources that was calculated to them according to Toronto formula. Evaluation the effect of two dietary regimens was done by measuring anthropometric measurement, laboratory investigation. The main results reveled decreased the length of hospital stay, decreased the change of anthropometric measurement, positive effect on serum albumin and total protein and a positive significant relation between dietary protein intake and serum hemoglobin level, serum albumin and total protein.
\end{abstract}

\section{Introduction}

Burns are one of the leading causes of death and disability worldwide. According to theWorld Health Organization (2011) estimated that there are over. 300,000 deaths each year from fire alone, with more deaths from scalds,electrical burn and other forms of burn. The great majority was found in low income and middle income countries with global mortality rate amounting to 4.8per 100,000per year ${ }^{(1-3)}$. Burn has been defined as loss of continuity of body surface due to coagulation and destruction of the skin and/or underlying tissues ${ }^{(4)}$. Regarding etiologic agents of burn injuries; burn usually results from an energy source that transfers heat to the body. The heat source may be thermal, chemical, electrical and radiation ${ }^{(5)}$. As regard, Thermal injuries: classified as either scalds burns which represent about $70 \%$ of burns by spilling hot liquids or being exposed to very hot bathing water. Scald burns tend to cause superficial dermal burns. The other cause related to thermal is flame burns which they are often associated with inhalational injury and other concomitant trauma. This type of burn injury tends to be deep dermal or full thickness. The final classification is contact burns that occur by touching objects which either has been extremely hot or the contact was for an abnormally long period. Contact burns tend to be deep dermal or full thickness ${ }^{(5)}$.

Burn varies in their severity. As might be expected, the degree of thermal injury depends upon both the temperature of the offending agent and the duration of thermal exposure. Generally exposure to temperature greater than $45 \mathrm{oc}$ leads to cellular damage and protein denaturation. The severity of burn injury depends on extent, depth, and location of burn injury, age of patient, etiologic agents involved, presence of inhalation injury, and coexisting injuries or preexisting illnesses. The American Burn Association has used these parameters to establish guidelines for the classification of burn severity. This classification creates 3 categories of burn injury ${ }^{(6-9)}$; these are, Minor burn injury includes burns involving less than $15 \%$ of total body surface area (TBSA) in adults, and full-thickness burns involving less than $2 \%$ of TBSA that do not present a serious threat of functional or cosmetic risk to eyes, ears, face, hands, feet, or perineum, Moderate burn injury includes partialthickness burns of $15-25 \%$ of total body surface area (TBSA) in adults, and full-thickness burns involving 2$10 \%$ of total body surface area (TBSA) that do not present serious threat of functional or cosmetic impairment of the eyes, ears, face, hands, feet, or perineum and finally, Major burn injury includes partial-thickness burns involving more than $25 \%$ of TBSA; full-thickness burns involving more than $10 \%$ of total body surface area $(\text { TBSA })^{(6-9)}$ 
Burns involving more than $20 \%$ of the body's surface area produce profound metabolic abnormalities fueled by the exaggerated stress response to the injury. The body's response has been classified as hyperdynamic, hypermetabolic, and hypercatabolic. Hypermetabolism begins at about the fifth post-burn day and persists for close to twenty-four months, causing loss of lean body mass, reduced bone density and muscle weakness and the degree of the response depends on the size of the burn and the patient's age, body composition, size, and genetic response to insult. Persistent hypermetabolism may last up to 1 year after burn injury ${ }^{(10)}$. Metabolic rate reach up to $200 \%$ of normal in extensive burn injuries ${ }^{(10-12)}$. This period is characterized by profoundly accelerated glycolysis, lipolysis, proteolysis, insulin resistance, liver dysfunction, and decreases of lean body mass (LBM) and total body mass. A $10 \%$ loss of total body mass leads to immune dysfunction; 20\% leads to decreased wound healing; 30\% leads to severe infections; and a $40 \%$ loss lead to death. So, that is why burned victims are predisposing to frequent infections, increased length of hospitalization, increased mortality and poor wound healing $\left({ }^{13-17)}\right.$.

Wound healing represents a dynamic process consisting of a high-integrated chronological sequence of biochemical, physiological and morphological changes. The same basic cellular and biochemical processes are involved in the healing of all soft-tissue injuries including burn. Chambers mentioned that three major phases of wound healing have been identified; Hemostatic (inflammatory), proliferative and maturation (remodeling) ${ }^{(18-20)}$. Nutritional support is recognized as one of the most significant aspects of care for the burned patient. Nutritional support with optimized protein intake can decrease protein losses by approximately $50 \%$ (Cioffi, 2000) in order to promote a state of positive nitrogen balance and fostering wound healing ${ }^{(21)}$.

\section{Aim Of The Study:}

The main aim of the study is to determine the effect of therapeutic dietary regimen on wound healing for patients with moderate degree burn.

\section{Material And Methods}

Material:

Design:

A quasi experimental design was used in the present study.

Setting:

The study was conducted at the Burn Unit of the Main Alexandria University Hospital.

Subjects:

A convenience sample of 66 recently burned patients (within the first $48 \mathrm{hrs}$ ) was selected according to power analysis (using the program epi-info to estimate the sample size) using the following parameters:

1. Population size 215

2. Expected frequency $50 \%$

3. Maximum error $10 \%$

4. Confidence coefficient $95 \%$

- The study sample was enrolled randomly into two equal groups (control group and a study group).

- The subject inclusion criteria was:

1. Age from 21 to 60 years

2. Recent moderate degree of burns (15-25\% total body surface area).

3. Free from diseases which recommend special dietary regimen including diabetes, cardiac disease, renal disease, cancer patients and endocrinal problems including hypothyroidism or hyperthyroidism.

Tools:

Tool I: Nutritional assessment tool: This tool was adopted from Bayyumi $2004^{(22)}$ to collect the necessary data and it was consisted of two parts:

Part 1: Anthropometric measurement, these include patient's weight (kg), height (meters), triceps skin fold, mid arm circumference, mid-arm muscle circumferences as well as body mass index (BMI). Each item was checked within 48 hours after admission and then was evaluated twice weekly until patients discharge.

Part 2:Laboratory investigations:these investigations were composed of complete blood count (CBC), total protein and serum albumin, serum $\mathrm{Na}+$ and $\mathrm{K}+$, renal function tests ( urea, creatinine) and liver function tests (bilirubin, SGOT,SGPT) was determine. Also, Wound culture swab was done for all subjects every 7 days.

Laboratory investigations were performed for all patients within 48 hours after admission and then were evaluated twice weekly until patients discharge.

Bio-Sociodemographic sheet was attached to tool I and it was include:

- Personal characteristics, including patient's age, sex and level of education, occupation and residence.

- Burn related data these data was composed the site of burn, total body surface area, degree of burn and causes of burn.

Tool II: Nutrient requirement assessment tool:This tool was developed by the researcher where calories and protein requirements for the patients was calculated by using Toronto formula ${ }^{(23)}$ 
$\operatorname{REE}(\mathrm{kcal})=-4343+(10.5 \times$ TBSA burned $)+(0.23 \times$ kcals $)+(0.84 \times$ Harris Benedict $)+(114 \times \mathrm{T}(\mathrm{oC}))-(4.5$ $\mathrm{X}$ days post-burn)

Where:

- $\quad \mathrm{REE}=$ resting energy expenditure

- $\mathrm{TBSA}=$ total body surface area burned.

- $\mathrm{kcals}=$ calorie intake in the past 24 hours

- $\mathrm{T}=$ body temperature in Celsius degrees.

- Days post-burn = the number of days after the burn injury is sustained using the day itself as day zero.

Harris Benedict $=$ basal requirements in calories using the Harris Benedict equation with no stress factors or activity factors

Estimations of caloric and protein requirements for study group were calculated within 48 hours after admission and then once per week until patients discharge.

Tool III: Food intake record:It was adopted from Ahmed $2003^{(24)}$ to assess patient's dietary intake daily until patients discharge. It included all types and amounts of food ingested by the subjects in the study. It was assessed daily from admission until patients discharge.

Tool IV: Evaluation tools:This tool was adopted from Bayumi $2004^{(22)}$

- Burn wound healing observation checklist. This included

- Morphological change of the wound was assessed in relation to the stages of wound healing. This was applied on admission then twice weekly until complete wound healing or patients' discharge.

- Complete wound healing includes:

- Presence of healthy granulation tissues.

- Proliferation of epithelial cells.

- Formation of eschar of the wound.

- Abnormal findings of wound healing include:

- Necrotic tissue.

- Local signs of infection (change of color of wound, exudates, edema and pain).

- Increased surface area of wound.

- Moist granulation tissues.

- Unchanged surface area of wound.

- Absence of epithelial edges.

- Other abnormalities including pus cells

Tool V: Nutritional burn plan:This tool was designed by the researcher. It included variables comparing two groups, as follow.

Group I (control group): This part was pertinent to patients who were receive the routine hospital diet. The number of calories and protein content were calculated within 48 hours after admission; this was done daily until patients discharge by using tool III (food intake record).

Group II(study group): This part was involve the nutritional regimen that was comprise high calories and protein diets mainly from natural nutrients that was supplemented to the patients. This diet was design individually for the study group and calculated according to Toronto formula where REE $(\mathrm{kcal})=-4343+(10.5$ $\mathrm{x}$ TBSA burned $)+(0.23 \mathrm{x}$ kcals $)+(0.84 \mathrm{x}$ Harris Benedict $)+(114 \mathrm{x} \mathrm{T}(\mathrm{oC}))-(4.5 \mathrm{x}$ days post-burn $)$

\section{Method}

- Written approval to carry out the study was obtained from the administrative office of the Faculty of Nursing and directors of the MUH hospital and the Burn Unit.

- Study tools were developed; Tool II (nutrient requirement assessment tool) and tool V (nutritional burn plan). These tools were tested for content validity by a jury of 7 experts in the field Medical Surgical Nursing and plastic surgery to assess content validity, clarity of the items, as well as comprehensiveness and relevance of the items.

- A Pilot study was conducted on 5 patients for testing, clarity, feasibility and applicability of the developed tools and modifications were done which was assessment of patients' nutrient requirement once per week instead of twice per week as a result of the change in calories was very small quantities.

- Written approval to carry out the study was obtained from ethical committee of the faculty of nursing.

- Written consent of the patients to participate in the study was obtained.

- $\quad$ Privacy of the patients was maintained.

- Confidentiality of the collected data was secured.

Statistical analysis:

- After data collection, data were coded and transformed into specially designed forms as to be suitable for computer feeding. All entered data were verified for any errors 
- The SPSS V 20.0 was used for the analysis of the data. Frequency tables and cross tabulations were used to illustrate the results of categorical data and tested by the Chi Square Test or Fisher's Exact Test. Quantitative data were summarized by the arithmetic mean and standard deviation. Comparison of means was done by Student t-test and One-Way Analysis of Variance (ANOVA).

\section{Results}

Table (1): shows that burn victims of the study group mostly were female (57.6\%), mostly (78.8\%)aged from (20-39years old), less than one third $(27.3 \%)$ were illiterate, one third $(39.4 \%)$ had manual work, two third $(69.69 \%)$ were from rural area, most of them had flam burn $(72.7 \%)$.

Table (2): illustrated that more than one third (39.39\%) of study group discharged at the end of the second week. In contrast there was no patient discharged at the end of the second week from the control group. Furthermore, all study group (100\%) discharged at the end of third week While, all control group (100\%) discharged at the end of sixth week.

Table (3): This table exhibited that all study group discharged at the end of third week and decreased in their body weight, TSF and MUAC $(1.3 \pm 1.49),(0.5 \pm 1.13)$ and $(1.1 \pm 1.04)$ respectively. While all control group discharged at the end of sixth week and decreased body weight, TSF and MUAC $\quad(-6.1 \pm 4.64),(2.8 \pm 1.67)$ and $(3.9 \pm 1.64)$ respectively. There was statistical significance relation between wound healing and body weight, TSF and MUAC in relation to study and control group where $\mathrm{P}$ value were $(0.014,0.035,0.012)$ respectively

Table (4): This table exhibited that all study group had complete burn wound healing at the end of third week and increased in caloric, protein, carbohydrate and fat intake $(2414.17 \pm 237.17),(90.91 \pm 6.35),(319.05 \pm 49.6)$ and (58.25 \pm 4.76$)$ respectively. In contrast all control group had complete burn wound healing at the end of sixth week and

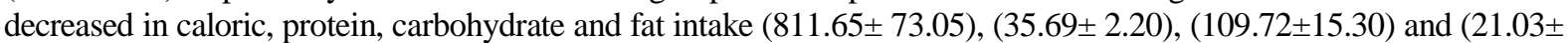
0.95) respectively. There was highly a statistical significant difference in relation to Macronutrient intake and complete wound healing among patients in the study and control group.

Table (5): This table illustrated that all the study group had complete burn wound healing at the end of third week and

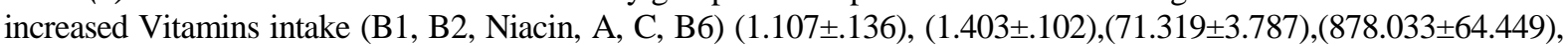

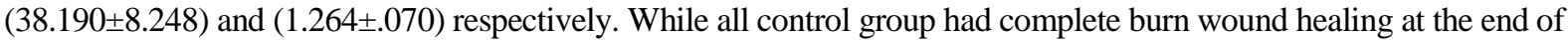

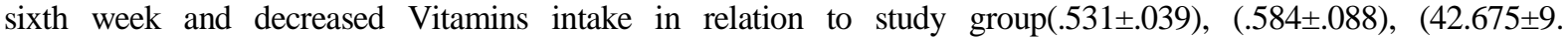
$834),(242.567 \pm 30.090)$, (35.813 \pm 6.575$)$ and $(.477 \pm .058)$ respectively. There was highly statistical significant difference in relation to Vitamins intake and wound healing among study and control group.

Table (6): This table showed that there were highly statistical significant in relation to mineral intake among study and control group. Concerning Sodium intake $(\mathrm{Na})$ the mean of study group at the end of third week when discharged was $(909.93 \pm 234.81)$ while the control group discharged at the end sixth week with mean $(298.64 \pm$ 48.30). As regard potassium intake (K) the study group had complete wound healing at the end of third week and the mean was $(1021.26 \pm 138.90)$ while as the control group discharged at the end of sixth week with mean (775.63 \pm 91.25). Furthermore, mean of calcium intake of study group at discharge was (1059.83 \pm 105.52$)$ where as mean of calcium intake of control group at discharge was (352.44 \pm 50.95$)$. In addition magnesium intake of study group was $(105.59 \pm 14.92)$ and in control group was $(75.29 \pm 7.63)$. As regard iron intake $(\mathrm{Fe})$ of study at discharged was (12.08 \pm 1.20$)$ while in control group was $(5.18 \pm 0.75)$. Concerning zinc intake of study

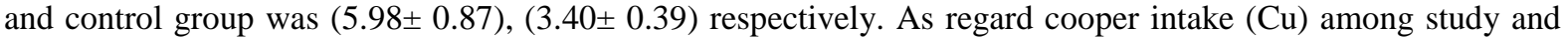
control group was $(0.60 \pm 0.06),(0.22 \pm 0.03)$ respectively. Finally phosphorous intake $(\mathrm{P})$ of study group was $(1361.23 \pm 117.88)$ while in control group was $(420.33 \pm 49.04)$. There was highly a statistical significant differencein relation to Minerals intake and wound healing among study and control group.

Table (7): In relation to bacteriological wound culture among study and control group this table revealed that, the majority $(81.8 \%)$ of the study group had negative bacteriological wound culture in the first week where as less than half $(45.5 \%)$ of control group had negative wound culture and one third had staph microorganism in the first week. Regarding the second week three quarter $(75.8 \%)$ of study group had negative wound culture and less than two third $(60.60 \%)$ of control group had staph microorganism. Concerning third week all the study group had negative wound culture while less than two third $(60.60 \%)$ of control group had staph microorganism. Table (8): This table illustrated the relation between macronutrient and micronutrient intake and serum hemoglobin level among study and control group. Concerning study group there was statistical relation between animal proteins, lipid animal, iron animal and Niacin intake and serum hemoglobin level where $\mathrm{P}$ value was $\left(.017^{*}, .021^{*}, .024^{*}\right.$ and $\left..031^{*}\right)$ respectively . While in control group there was no statistical significance relation between Hemoglobin and Macro and Micronutrients intake.

Table (9): This table illustrated the relation between macronutrient and micronutrient intake and serum albumin level among study and control group. Concerning study group there was statistical significance relation between protein plant intake and serum albumin levelwhere $\mathrm{P}$ value was $(.044 *)$. While in the control group there was statistical significance relation between albumin and vitamin $\mathrm{A}$ intakewhere $\mathrm{P}$ value was $\left(.035^{*}\right)$. 
Table (10): This table illustrated the relation between macronutrient and micronutrient intake and total protein level among study and control group. Concerning study group there was statistical relation between protein plant intake and serum albumin levelwhere $\mathrm{P}$ value was $\left(.044^{*}\right)$. While in the control group there was statistical significance relation between serum total protein and Calcium intakewhere $\mathrm{P}$ value was $\left(.010^{*}\right)$.

\section{Discussion}

Burn patients with more than $20 \%$ body surface area injury suffer a long and severe response to injury, including a hyperdynamic and hypermetabolic response with lipolysis, proteolysis, glycolysis, and fever. This catabolic state ultimately results in a profound reduction of lean body mass. Poor wound healing, immune dysfunction, multiorgan failure, and even death can ensued ${ }^{(25)}$. Nutritional support is an important step in the management of burns patients from the early phase of resuscitation to the final phase of rehabilitation. Nutritional support is defined as the provision of nutrients and any necessary adjunctive therapeutic agents to improve or maintain the nutritional status of the patient for normal wound healing. Machado (2011) and Rousseau (2013) reported that nutritional therapy is an integral part of burns care and it involves nutritional assessment and nutritional support. The main goals of nutritional therapy for burned patients is maintaining body mass, restoring protein losses, managing infection as well as preventing starvation and specific nutrient deficiencies (Prins 2009) ${ }^{(26-28)}$.

Burn management needs multidisciplinary approach with an effort from various specialties in the team. The dietitian in the burn team has a defined role in the care of the burned patients, from the acute phase until the rehabilitation phase and they had a role in the assessment, treatment and management of nutritional requirements so, the present study's aim is to determine the effect of nutritional regimen among moderately burned patients on wound healing through using clinical data and anthropometric measurement (29). Anthropometric measurement especially body weight is considered the easiest indicator and perhaps the best way to assess the nutritional status ${ }^{(144)}$. This study exhibited that there was a significant relation between wound healing and (body weight, TSF and MUAC) change at discharge where all the study group had complete burn wound healing and discharged at the end of the third week with decreased in anthropometric measurement were less than the control group as they discharged at the end of the sixth week. This may be justified as a result of the effect of therapeutic dietary regimen on promoting wound healing. In addition, the pathophysiology reveals hypermetabolism that lead to an increased rate in the utilization of nutrients and hypercatabolism that enhances the breakdown of muscle and fat. Furthermore, the study group received explanation about the importance of nutritional therapy on wound healing which result in decreased the length of hospital stay of the study group than the control group. These results come in the line with Curreriet al (1974) and Wilmore et al (1971) who had shown that patients with $40 \%$ TBSA burn have lost up to one-quarter of their preadmission weight by 21 days post injury and only through aggressive nutritional replacement using $25 \mathrm{kcal} / \mathrm{kg}$ body weight and $40 \mathrm{kcal}$ per percent TBSA burn per day, that body weight is parrely maintained in burned adults ${ }^{(30,31)}$.

Also, Ahmed's (2003) study- on effect of nutrition on graft taking for burned patients found a decreased in mean body weight value in all patients in second assessment post graft as compared with their admission weight. Furthermore, Hemeda (2009) in her study nutritional needs of post traumatic critically ill patients clarified that there was a significant decline in anthropometric measurement as regard (body weight, triceps skin fold and mid upper arm circumference) ten days after patients admission when compared to admission anthropometric measurement. In addition, Bader et al (2000) who monitored adult ventilator dependent patients' responses to nutritional support schedule throughout three weeks. Their results documented a decline of anthropometric measurement mean values during the second and the third weeks as compared to the first week Also, Rousseau (2013) reported that burned patients had hypermetabolism that lead to an increased rate in the utilization of nutrients and hypercatabolism that enhances the breakdown of muscle and fat ${ }^{(24,27,32,33)}$. Concerning clinical data following burn injury the present study revealed that decreased serum hemoglobin, Hematocrit and white blood cell at discharge for both study and control group, but the decrease in the study group was less than the control group. It could be justified as the effect of therapeutic diet on maintaining or decreasing the change of laboratory investigation. Also, fastening wound healing improves patients' physical and psychological status and thus on consequence enhance patients to consume the calculated caloric intake. This result go in the same line with, Bolarinwa et al (1991) who had shown the relative importance of some animal and vegetable protein diets in the formation and composition of blood. Also, they reported that several protein-rich diets have been shown to increase both hematocrit levels and hemoglobin concentrations ${ }^{(34)}$.

Moreover, Berger et al (2006) found that serum Fe, Selenium and $\mathrm{Zn}$ levels decreased after burn injuries. Also, they reported that serum copper was severely decreased and thus on consequence affect on serum hemoglobin level. Additionally, other studies had also shown that regular daily supplementation of iron to hospitalized patients can significantly contribute to reduction in anemia prevalence (Gopalan, 2003). ${ }^{(35,36)}$. 
As regard, serum albumin and total protein, it was noticed that there were increased in study group more than in control group at discharge. It may be justified as effect planed diet and decreased length of hospital stay. This result is supported by Castaneda et al (1995) who reported that serum albumin concentration may be a marker of protein status of the body. Furthermore, Amir (2012) found that albumin levels were one of the most significant independent predictors of poor wound healing outcomes in chronic wounds. This result is contradicted by Vanek(1998) who reported that serum albumin is a poor nutritional marker, but it is a good prognostic marker correlating with morbidity and mortality in hospitalized patients. For that reason, it's hardly surprising that hypoalbuminaemia is associated with increased mortality and prolonged length of stay in ICU ${ }^{(37-}$ 40)

Prins (2009) reported that choosing the proper level and source of energy is one of the most critical aspects of helping patients recover from a severe burn ${ }^{(28)}$. In this respect, the present study showed a positive significant relation among macronutrient intake and wound healing of the study group than control group. This result may be due to that, the study group received planned diet which composed of carbohydrate, protein and fat. Also, this diet contained wheat germ. This planned diet based on Toronto formula that focused on patients body weight, height, days post burn, body temperature and Harries Benedict equation while the control group received routine hospital diet. This result is in line with Prins (2009) who reported that carbohydrate is much preferred energy substrates for macrophages, leucocytes and fibroblasts. Also, Lee (2011) revealed that, patients who were fed with low fat and high carbohydrate diet had shorter ICU stays per \% TBSA of burn, and lower incidence of sepsis and survived better than persons who were given a high fat diet. In addition, A'Beckett et al (2011) reported that the estimation of macro and micronutrient are dependent on the weight, height, age, sex and Total Burns Surface Area (TBSA) ${ }^{(28,41,42)}$.

Furthermore, Williams (2003) stated that, carbohydrates is the major source of energy for burned patients because they serve as fuel required for wound healing, provides glucose for metabolic pathways and spares amino acids that are needed for catabolism in the patients. So, high carbohydrates diet increased protein synthesis, increased endogenous insulin production, and improved lean body mass and muscle protein synthesis. from the otherwise, Aryee et al. (2011) recorded that majority of the patients had low energy and protein intake when their intakes were compared with their requirements and thus on consequence affect of the wound healing process ${ }^{(43,44)}$. Concerning fat intake, Lee et al (2011) found that excessive intake of fats can lead to increase the infection rate in burned patients, but adequate amounts are beneficial in diverse ways. This result was in line with Erridge et al (2007) who stated that foods high in fats induces endotoxema which leads to wound infection, hence fat should be limited in burned patients. Also, Masters et al (2012) reported that high carbohydrates, high protein and low fat enteral feeding reduced the incidence of pneumonia as compared to low carbohydrates, high protein and high fat enteral feeding ${ }^{(45-47)}$.

Additionally, Prins (2009) clarified that extra proteins are needed for the burn patient due to the release of stress hormones and cytokine that leads to mobilization of lean body mass. An increase in cortisol levels also stimulates proteolysis, and oxidation of proteins and the rate at which lean body mass is eroded from a burn patient which is proportional to the extent of injury increases the protein needs of the individual. Again, Prins (2009) reported that an imbalance of protein degradation and protein synthesis leading to muscle weakness and delay wound healing. So, adequate amounts of protein in the burned patient of $1.5 \mathrm{~g} / \mathrm{kg}$ body weight are recommended ${ }^{(28)}$. Moreover, Williams et al (2010) reported that an increase in protein is known to be beneficial to the burned patients on enhancing wound healing. More and more, Peng et al (2005) found that when protein supplemented at a rate of $0.5 \mathrm{~g} / \mathrm{kg} /$ day for burned patients they were capable of reversing the changes made during the burn. Also, Young et al and Ryan (1995) concluded that burned patients had 50\% higher use rates of essential and nonessential amino acids than healthy individuals. Similarly, Matthews et al (1993) and Saffle (2007) showed that burned patients require a minimum of 1.5 to $2 \mathrm{~g} / \mathrm{kg}$ body weight per day protein intake for improving wound healing and reduced catabolic state ${ }^{(48-51)}$.

Furthermore, Adams 2002 and Shewry 2009 explained that wheat germ was considered good source of caloric, protein, minerals, B-group vitamins and dietary fiber. In addition, several studies noted that wheat germ contained carbohydrate $78.10 \%$, protein $14.70 \%$, fat $2.10 \%$, minerals $2.10 \%$ and considerable proportions of vitamins (thiamine and vitamin-B) and minerals (zinc, iron). Also it considered a good source of traces minerals like selenium and magnesium, nutrients essential to wound healing. Hadjivassiliou 2003 concluded that wholewheat grain supplies elements needed by the human body as Starch and gluten which provide heat and energy; phosphates and other mineral salts, vitamins B and E and protein that help in building and repairing of muscular tissue ${ }^{(52-57)}$ As regard the relation between macro, micronutrient and hemoglobin level, serum albumin and total protein the present study illustrated that there was a positive significant relation between dietary protein intake and hemoglobin level, serum albumin and total protein. Due to the fact that protein metabolism enhance albumin synthesis. This result in line with Caso et al (2007) identified that ingestion of dietary protein alone as the important factor, compared to ingestion of carbohydrates and fat, for the stimulation of albumin synthesis. Furthermore, several studies showed that ingestion of dietary protein positively influences albumin 
synthesis. Also, Naber et al (1997) showed that low albumin concentration has been used as a marker of protein malnutrition. In addition, World Health Organisation 2005reported that Iron deficiency could also be due to inadequate folic acid, riboflavin, copper, vitamin A, \& B12 and zinc intake. Furthermore, Martínez et al (2000) stated that heme iron absorption is less affected by substances in the diet than non-heme iron, indicating that heme iron absorption is determined mainly by the body iron levels and, to a very minor extent, by dietary factors $^{(58-63)}$.

Al - Jawad et al (2011) stated that the main cause of immune suppression in burned patients is as a result of the presence of reactive oxygen species (ROS) which delay wound healing and increased the patient's susceptibility to infections. Again, Al-Jawad et al (2011) reported that low levels of anti-oxidants coupled with high levels of free radicals leads to a remarkable delay in wound healing. In addition, A'Beckett et al (2011) specified that micronutrient needs are elevated in burned patients due to urine and cutaneous losses and diminished gastro intestinal absorption and provision of at least the Required Daily Intakes (RDI) is good for wound healing. Also, a study by Aryee et al. (2011) reported that all the burn patients had micronutrient deficiencies ${ }^{(42,44,64)}$. In this respect, the present study illustrated that there was a positive significant relation between vitamins intake (B1, B2, Niacin, $\mathrm{A}, \mathrm{C}, \mathrm{B6})$, mineral intake $(\mathrm{Na}, \mathrm{K}, \mathrm{Ca}++, \mathrm{Mg}, \mathrm{P}, \mathrm{Fe}, \mathrm{Zn}$ and $\mathrm{Cu})$ and wound healing. This results due to the fact that pathophysiology of burn causes loss of micronutrient through burn wound and presence of reactive oxygen species (ROS). This result is congruent with, Berger et al (2007) who reported that there was a positive correlation between the free radical cascade and wound healing. Furthermore, Kurmis et al. (2013) reported that a deficiency in antioxidant micronutrients that is very common in burns lead to delayed wound healing, increase in the presence of infection as well as increasing the length of hospital stay. In addition, Barbosa (2009) reported that there were clinical benefits have been shown with reduction of oxidative stress, and improved wound healing using doses of vitamin $\mathrm{C}$ and $\mathrm{E} 1.5-3$ times higher than recommended daily intakes. So, these findings strongly support the use of anti-oxidants in nutritional therapy for burned patients ${ }^{(65-67)}$.

Moreover, Prins (2009) illustrated that, patients with TBSA greater than $30 \%$ lose 20 to $40 \%$ of copper and $10 \%$ of selenium and zinc in the first week post burns. Additionally, in the presence of inhalational injury, there was a decrease in Vitamin E. Similarly, Berger (2007) stated that supplementation of micronutrient in a burned patient is known to increase the rate of wound healing and reduce infections. Furthermore, Berger et al (2006) noted that there were multiple micronutrient used as an intervention had a positive effect on wound healing, infection rate, protein turn over and protein catabolism ${ }^{(28,35,67)}$. In addition, MacKay et al (2003) illustrated that vitamin $\mathrm{C}$ (ascorbic acid) influences all phases of wound healing such as the inflammatory phase, proliferative phase, and maturation, synthesis, and degradation of collagen. Also, it is responsible for neutrophil migration to the site of injury and has a role in clotting when the skin is exposed. Again, MacKay (2003) reported that vitamin $\mathrm{C}$ supplementation enhanced neutrophils mortility to chemotactic stimulus and stimulation of lymphocyte transformation and decrease the length of wound healing time. This corresponds to the work done by Barbosa et al (2009) and Sahib et al (2010) who noted that the supplementation of vitamin C reduced wound healing time ${ }^{(25,29,68)}$.

Mackay et al (2003) concluded that vitamin A play diverse roles in the wound healing cascade, enhances early inflammatory phase and promotes epithelial cell differentiation, collagen deposition, and enhance immunity that contributing to wound healing. Moreover, Noori (2012) found that patients with adequate dietary intake of vitamin $\mathrm{A}$ had progress in wound healing during $2^{\text {th }}$ and $3^{\text {rd }}$ weeks. As well as, increase in lymphocyte proliferation which has the ability to prevent wound infection due to the reduction of microbes on wounds ${ }^{(25,69)}$. More and more, Rojas (1999) presented that zinc deficiency is associated with impaired wound healing ${ }^{(70)}$. Furthermore, Dorner (2013) recommend zinc supplementation for up to 10 days enhance wound healing ${ }^{(71)}$. Also, Berger et al (2007) who found that adequate intake of trace element enhance wound healing and the recovery of burn patients as evidenced by reduced length of hospital stay ${ }^{(67)}$. In addition, the study done byWilliams (2003) reported that deficiency of zinc may decrease rates of fibroplasia, epithelialization, and collagen synthesis as well as wound strength and impair immune response, increasing susceptibility to recurrent infections ${ }^{(43)}$. This finding was similarly to the finding of the study done by Kohn (2000) and Cario (2000) ${ }^{(72,73)}$.

Moreover, Voelker (2000) reported that copper-induced proliferation of endothelial cells and thus on consequence promotes wound healing. This finding was similar to the study done by Borkow (2004). Also, Tenaud et al (1999) showed that zinc, copper and manganese enhance cellular mobility in the Proliferation Phase of wound healing and suprabasally differentiated keratinocytes during the final phase of wound healing.. Furthermore, the Trumbo et al (2001) recommended daily allowance of $0.9 \mathrm{mg}$ of copper for promoting wound healing ${ }^{(74-77)}$. Furthermore, Williams (2003) found that deficiencies of vitamin B had an indirect effect on wound healing by decreasing host resistance because of impaired antibody formation and white blood cell function, which also increases susceptibility to wound infections and on consequence delay wound healing ${ }^{(43)}$. Also,Todorovic (2002) found that deficiency of iron may cause increased tissue ischemia, impaired collagen formation, and decreased wound strength ${ }^{(78)}$. Additionally, Kapur et al (2003) they illustrated that nutrition 
education had a positive effect on the iron status possibly by improving the dietary iron intake.This result was contradicted by Saffle and Graves (2007) who stated that it was unclear whether additional micronutrient supplementation is of benefit to burned patients ${ }^{(79,80)}$. Infection in the burn patient is a leading cause of morbidity and mortality and remains one of the most challenging concerns for the burn team. In the light of this, the present study revealed that the majority of study group had a negative bacteriological wound culture which indicated that the occurrence of wound infection rate was less than control group. This exhibited that the effect of therapeutic dietary regimen that enhance the immune system which decrease the risk of wound infection. Also, from the present study, the entire study group discharged at the end of the third week which means decreasing their hospital length of stay that reduced the susceptibility of hospital acquired infection. This result go in the same line with McClave and Heyland (2009) who noted that enteral nutrition in ICU patients serves to suppress systemic immune response, decrease oxidative stress, and promote favorable patient outcomes, such as reduced incidence of bacterial infections, decreased in hospital length of stay, and reduced mortality ${ }^{(81)}$.

Furthermore, several studies had shown that early enteral nutrition (EEN) is associated with decreased patients length of hospital stay.Similarly, Mosier et al (2011) observed that the enteral nutrition (ENT) initiated within the first 24 hours after admission was related to shorter ICU stay and the incidence of wound infection. Also, Rimdeika et al (2005) reported that burned patients receiving 30kcal/kg during 24 hours had lower sepsis, pneumonia and mortality rate, with shorter duration of treatment. In addition, Suri et al (2006) showed a reduction in mortality and length of hospital stay (LOS) in burned patients who nourished aggressively ${ }^{(82,86)}$.

Similarly Khorasani et al (2009) concluded that early enteral nutrition had a positive indicator for shorting LOS and decreasing mortality ${ }^{(87)}$. Furthermore, Berger et al (2007) and Berger et al (2006) reported that trace element supplementation reduced wound infection rates ${ }^{(35,76)}$. Also, Bryd-Bredbenner et al (2013) reported that selenium play a role in immune function hence wound healing. Furthermore, Hart et al (2003) found that aggressive feeding attenuated muscle catabolism and improved infection outcomes after burn injuries ${ }^{(88,89)}$. This result is incongruent with Ahmed (2003) revealed that the result of wound culture for all patients in both study and control group were positive. Similarly, study done at the burn unit of Tanta Casualty University Hospital by Ragab (2002) confirmed that burn wound bacteriological culture were highly positive ${ }^{(24,90)}$. Furthermore, Minard et al (2000) did not find a significant difference in length of stay or infection in early enteral nutrition (EEN) in severe brain injury patients. Also, Dvorak et al. (2004) failed to show a significant difference in infection, nutritional status, feeding complications, number of hours on a ventilator, or length of stay in patients with acute cervical spinal cord injuries who were fed early enteral nutrition (EEN) versus late enteral nutrition $(\mathrm{EN})^{(91,92)}$.

There are many factors that affecting the wound healing process, it began from the types of dressings used to the status of patient's nutritional health. Age also has a massive effect on how quickly and well patients recover. As patient get older, they experience physiological changes that may put them at a greater risk of poor healing. In this respect, the present study showed that the highest mean of macronutrient (caloric, protein, fat and carbohydrate) and micronutrient intake were found in the study group between (20-29 years old). This result go in the same line with Mogford et al (2002) reported that diminished wound healing capabilities often observed in old aged patients ${ }^{(93)}$. Also, WHO (2005) stated that age has an impact on wound healing ${ }^{(94)}$. Furthermore, Chernoff (2004) reported that the elderly patients had an increased need for exogenous protein of at least $1.0 \mathrm{~g} / \mathrm{kg}$ of body weight for normal maintenance and that inadequate protein intake contributes to a decrease in the reserve capacity, increased skin fragility, and decreased immune function, poorer healing, and longer recuperation after illness ${ }^{(95)}$. Furthermore, Dorner et al 2012 and Thompson 2005 concluded that Caloric needs during wound healing are estimated at 30$35 \mathrm{kcal} / \mathrm{kg}$, or up to $40 \mathrm{kcal} / \mathrm{kg}$ if the patient was underweight, but may need to be individualized based on age, comorbidities, body weight, activity level, stage of the healing process and the severity, size, and number of wound $^{(96,97)}$.

The American College of Chest Physicians suggests that enteral nutrition should be initiated as soon as possible after resuscitation. Burn patients frequently receive inadequate nutrition, initially because of hemodynamic instability and paralytic ileus. Eventually, nutrition is still inadequate due to required fasting for surgical procedures or diagnostic exams, the difficulty in chewing solid foods because of facial burns and due to anorexia and vomiting ${ }^{(98,99)}$. In light of this, the present study found that nearly one third of the study group could not meet their caloric requirement through nutrient intake only but they need dietary supplement with Sustagen. It may be due to the increase of caloric requirement for burned patient more than 5.000 Kcal/ day which were difficult on the patients to eat this amount of diet. This result go in the same line with Chan et al 2008 indicated that metabolic rates in burn patients are often double normal rates and that their demand for caloric requirement more than 5,000 calories daily ${ }^{(100)}$. From forgoing discussion, it can be noticed that adequate nutrition has an important impact on burned patients as it fastening burn wound healing, decreasing the change of anthropometric measurement and clinical data and finally decreasing the length of hospital stay. 


\section{Conclusion}

Patients who met their daily requirements of macronutrients intake (caloric, protein, carbohydrate and fat), micronutrients (vitamin as vitamin A, C, B1, B2, Niacin and B6) and mineral intake ( $\mathrm{Na}, \mathrm{K}, \mathrm{Ca}, \mathrm{Mg}, \mathrm{P}, \mathrm{Fe}$, $\mathrm{Zn}$ and $\mathrm{Cu}$ ) had a positive effect on their wound healing outcomes, decreasing wound infection rates, decrease the change in laboratory investigation andfinally decrease the length of hospital stay.

\section{Recommendations}

1. The presence of dietitian among the burn team in burn unit is extremely necessary.

2. Presence of instructional booklet that contains Toronto formula and nutritional plans in order to facilitate the calculation of caloric requirement.

3. Performing continuous nutritional assessment for all admitted patients in burn unit.

4. Provision of needed equipment for assessing nutritional status, as skin fold calipers, non-stretchable tape measurement and body weight scales.

5. Continuous educational program for all nursing staff and those involving in patients care about nutritional assessment tools and calculation of caloric requirement.

6. Specialized burn care nurse that helping the patients to eat the therapeutic diet.

For organization, provide fund in order to perform certain laboratory investigation as serum prealbumin, serum transfrern and nitrogen balance for accurate assessing nutritional status for burned patients.

Table I: Frequency Distribution of Socio-Demographic Characteristics and burn related data among Study and Control Group.

\begin{tabular}{|c|c|c|c|c|c|c|}
\hline \multirow{2}{*}{\multicolumn{2}{|c|}{ Socio-Demographic Characteristics }} & \multicolumn{2}{|c|}{$\begin{array}{l}\text { Study group } \\
\mathrm{No}=33\end{array}$} & \multicolumn{2}{|c|}{$\begin{array}{l}\text { Control group } \\
\mathrm{No}=33\end{array}$} & \multirow[t]{2}{*}{$\begin{array}{l}\text { Significance } \\
\text { level } \chi^{2} \mathrm{P}\end{array}$} \\
\hline & & No & $\%$ & No & $\%$ & \\
\hline \multirow[t]{2}{*}{ Sex } & Male & 14 & 42.4 & 18 & 54.5 & \multirow{2}{*}{$\begin{array}{l}0.971 \\
0.324 \\
\end{array}$} \\
\hline & Female & 19 & 57.6 & 15 & 45.5 & \\
\hline \multirow[t]{3}{*}{ Age } & $20-29$ & 13 & 39.4 & 14 & 42.42 & \multirow{3}{*}{$\begin{array}{l}5.961 \\
0.114\end{array}$} \\
\hline & $30-39$ & 13 & 39.4 & 11 & 33.3 & \\
\hline & 40 or more & 7 & 21.2 & 8 & 24.2 & \\
\hline \multirow{4}{*}{$\begin{array}{ll}\text { Level } & \text { of } \\
\text { education }\end{array}$} & Illiterate & 9 & 27.3 & 12 & 36.4 & \multirow{4}{*}{$\begin{array}{l}3.363 \\
0.339\end{array}$} \\
\hline & read \& write & 4 & 12.1 & 3 & 9.1 & \\
\hline & Diploma & 15 & 45.5 & 17 & 51.5 & \\
\hline & bachelor degree & 5 & 15.2 & 1 & 3.0 & \\
\hline \multirow[t]{4}{*}{ Occupation } & manual work & 13 & 39.4 & 20 & 60.6 & \multirow{4}{*}{$\begin{array}{l}11.965 \\
0.008\end{array}$} \\
\hline & clerical work & 4 & 12.1 & 0 & 0.0 & \\
\hline & no work & 15 & 45.5 & 7 & 21.2 & \\
\hline & Other & 1 & 3.0 & 6 & 18.2 & \\
\hline \multirow[t]{2}{*}{ Residence } & Rural & 23 & 69.69 & 19 & 57.57 & \multirow{2}{*}{$\begin{array}{l}0.551 \\
0.458\end{array}$} \\
\hline & Urban & 10 & 30.30 & 14 & 42.42 & \\
\hline \multirow[t]{2}{*}{ Cause of burn } & flame & 24 & $72.7 \%$ & 30 & $90.9 \%$ & \multirow{2}{*}{$\begin{array}{l}3.667 \\
0.056^{*}\end{array}$} \\
\hline & scalds & 9 & $27.3 \%$ & 3 & $9.1 \%$ & \\
\hline \multirow[t]{16}{*}{ Site of burn } & head & 11 & $33.3 \%$ & 14 & $42.4 \%$ & \multirow{16}{*}{$\begin{array}{l}27.414 \\
0.052 *\end{array}$} \\
\hline & A. trunk & 12 & $36.4 \%$ & 21 & $63.6 \%$ & \\
\hline & Rt. buttock & 1 & $3.0 \%$ & 1 & $3.0 \%$ & \\
\hline & Rt. U. arm & 25 & $75.8 \%$ & 26 & $78.8 \%$ & \\
\hline & Rt. L. arm & 27 & $81.8 \%$ & 28 & $84.8 \%$ & \\
\hline & Rt. thigh & 6 & $18.2 \%$ & 13 & $39.4 \%$ & \\
\hline & Rt. leg & 11 & $33.3 \%$ & 7 & $21.2 \%$ & \\
\hline & Rt. foot & 15 & $45.5 \%$ & 6 & $18.2 \%$ & \\
\hline & Neck & 7 & $21.2 \%$ & 12 & $36.4 \%$ & \\
\hline & post trunk & 2 & $6.1 \%$ & 3 & $9.1 \%$ & \\
\hline & Lt. buttock & 1 & $3.0 \%$ & 1 & $3.0 \%$ & \\
\hline & Lt. U. arm & 16 & $48.5 \%$ & 20 & $60.6 \%$ & \\
\hline & Lt. L. arm & 22 & $66.7 \%$ & 23 & $69.7 \%$ & \\
\hline & Lt. thigh & 6 & $18.2 \%$ & 9 & $27.3 \%$ & \\
\hline & Lt. leg & 7 & $21.2 \%$ & 4 & $12.1 \%$ & \\
\hline & Lt. foot & 7 & $21.2 \%$ & 2 & $6.1 \%$ & \\
\hline \multirow{2}{*}{$\begin{array}{l}\text { Total body } \\
\text { surface area } \%\end{array}$} & 15 to $19 \%$ & 28 & $84.8 \%$ & 21 & $63.6 \%$ & \multirow{2}{*}{$\begin{array}{l}3.882 \\
0.049 *\end{array}$} \\
\hline & 20 to $25 \%$ & 5 & $15.2 \%$ & 12 & $36.4 \%$ & \\
\hline
\end{tabular}


Table (2): Distribution of length of hospital stays among study and control group

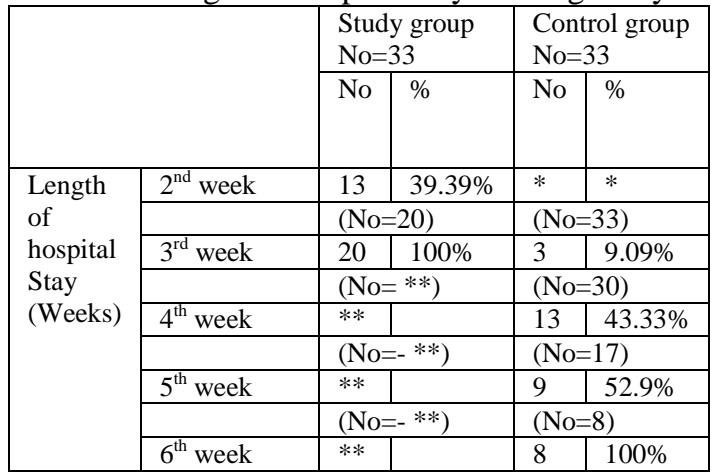

* Not discharge $\quad * *$ Discharge

Table (3): The relationship between wound healing and change of anthropometric change at discharge among study and control group

\begin{tabular}{|c|c|c|c|c|c|c|c|}
\hline \multicolumn{7}{|c|}{ Weight change at discharge } & \multirow{3}{*}{$\begin{array}{l}\text { Level of } \\
\text { significance } \mathrm{P}\end{array}$} \\
\hline & & \multicolumn{2}{|c|}{$\begin{array}{l}\text { Study group } \\
\mathrm{No}=33\end{array}$} & \multicolumn{3}{|c|}{$\begin{array}{l}\text { control group } \\
\mathrm{No}=33\end{array}$} & \\
\hline & & No & Mean \pm SD & No & \multicolumn{2}{|c|}{ Mean \pm SD } & \\
\hline \multirow{5}{*}{$\begin{array}{l}\text { Complete burn wound } \\
\text { healing }\end{array}$} & at the end of 2th week & 13 & $-.5 \pm 0.76$ & $*$ & \multicolumn{2}{|l|}{$*$} & \\
\hline & at the end of 3rd week & 20 & $-1.3 \pm 1.49$ & 3 & \multicolumn{2}{|c|}{$-3.7 \pm 1.15$} & $\begin{array}{l}2.653 \\
0.014 *\end{array}$ \\
\hline & at the end of 4th week & $* *$ & $* *$ & 13 & \multicolumn{2}{|c|}{$-3.7 \pm 2.39$} & \\
\hline & at the end of 5th week & $* *$ & $* *$ & 9 & \multicolumn{2}{|c|}{$-5.0 \pm 1.00$} & \\
\hline & at the end of 6th week & $* *$ & $* *$ & 8 & \multicolumn{2}{|c|}{$-6.1 \pm 4.64$} & \\
\hline \multicolumn{8}{|l|}{ TSF change at discharge } \\
\hline & & \multicolumn{2}{|c|}{$\begin{array}{l}\text { Study group } \\
\mathrm{No}=33\end{array}$} & \multicolumn{3}{|c|}{$\begin{array}{l}\text { control group } \\
\mathrm{No}=33\end{array}$} & \\
\hline & & No & Mean \pm SD & No & \multicolumn{2}{|c|}{ Mean \pm SD } & \\
\hline \multirow{5}{*}{$\begin{array}{l}\text { Complete burn wound } \\
\text { healing }\end{array}$} & at the end of 2th week & 13 & $-.1 \pm 0.22$ & $*$ & \multicolumn{2}{|c|}{$*$} & \\
\hline & at the end of 3rd week & 20 & $-.5 \pm 1.13$ & 3 & \multicolumn{2}{|c|}{$-1.0 \pm 0.0$} & $\begin{array}{l}2.25 \\
0.035^{*}\end{array}$ \\
\hline & at the end of 4th week & $* *$ & $* *$ & 13 & \multicolumn{2}{|c|}{$-3.0 \pm 1.41$} & \\
\hline & at the end of 5th week & $* *$ & $* *$ & 9 & \multicolumn{2}{|c|}{$-4.0 \pm 2.0$} & \\
\hline & at the end of 6th week & $* *$ & $* *$ & 8 & \multicolumn{2}{|c|}{$-2.8 \pm 1.67$} & \\
\hline \multicolumn{8}{|c|}{ MUAC change at discharge } \\
\hline & & \multicolumn{3}{|c|}{$\begin{array}{l}\text { Study group } \\
\mathrm{No}=33\end{array}$} & \multicolumn{2}{|c|}{$\begin{array}{l}\text { control group } \\
\mathrm{No}=33\end{array}$} & \\
\hline & & No & Mean \pm SD & & No & Mean \pm SD & \\
\hline \multirow{5}{*}{$\begin{array}{l}\text { Complete burn wound } \\
\text { healing }\end{array}$} & at the end of $2^{\text {th }}$ week & 13 & $-.1 \pm .22$ & & $*$ & $*$ & \\
\hline & at the end of 3rd week & 20 & $-1.1 \pm 1.04$ & & 3 & $-3.0 \pm 1.73$ & $\begin{array}{l}2.729 \\
0.012 *\end{array}$ \\
\hline & at the end of 4th week & $* *$ & $* *$ & & 13 & $-4.1 \pm 2.22$ & \\
\hline & at the end of 5th week & $* *$ & $* *$ & & 9 & $-4.8 \pm 1.92$ & \\
\hline & at the end of 6th week & $* *$ & $* *$ & & 8 & $-3.9 \pm 1.64$ & \\
\hline
\end{tabular}

$*$ not discharge $* *$ dischargeLevel of significance $\mathrm{p}=\leq 0.05$

Table (4): Mean and standard deviation of Macronutrient intake according to duration until complete burn wound healing

\begin{tabular}{|c|c|c|c|c|c|c|c|}
\hline \multirow[b]{2}{*}{ Macronutrient } & \multicolumn{2}{|l|}{ Study group } & \multicolumn{4}{|l|}{ Control group } & \multirow{2}{*}{$\begin{array}{l}\text { Significance } \\
\text { level } \\
\text { ANOVATest }\end{array}$} \\
\hline & $\begin{array}{l}\text { at the end } \\
\text { of } 2 \text { th week }\end{array}$ & $\begin{array}{l}\text { at the end of } \\
\text { 3rd week }\end{array}$ & $\begin{array}{l}\text { at the end of } \\
\text { 3rd week }\end{array}$ & $\begin{array}{l}\text { at the end of } \\
\text { 4th week }\end{array}$ & $\begin{array}{l}\text { at the end of } \\
\text { 5th week }\end{array}$ & $\begin{array}{l}\text { at the end of } \\
\text { 6th week }\end{array}$ & \\
\hline $\begin{array}{ll}\text { Caloric } & \text { intake } \\
\text { Mean } \pm & \\
\text { SD } & \end{array}$ & $\begin{array}{l}2194.47 \pm .31 \\
6.41\end{array}$ & $\begin{array}{l}2414.17 \pm \\
237.17\end{array}$ & $\begin{array}{l}1133.77 \pm \\
340.95\end{array}$ & $\begin{array}{l}974.03 \pm \\
157.85\end{array}$ & $\begin{array}{l}891.23 \pm \\
176.83\end{array}$ & $\begin{array}{l}811.65 \pm \\
73.05\end{array}$ & $\begin{array}{l}\text { F 494.351 } \\
\text { P .000 }\end{array}$ \\
\hline ProteinMean \pm SD & $\begin{array}{l}85.15 \pm \\
10.81\end{array}$ & $90.91 \pm 6.35$ & $51.15 \pm 11.33$ & $41.41 \pm 7.25$ & $39.08 \pm 8.61$ & $35.69 \pm 2.20$ & $\begin{array}{l}\text { F493.439 } \\
\text { P.000 }\end{array}$ \\
\hline $\begin{array}{l}\text { CarbohydrateMea } \\
\mathbf{n} \pm \text { SD }\end{array}$ & $\begin{array}{l}279.36 \pm \\
53.21\end{array}$ & $\begin{array}{l}319.05 \pm \\
49.62\end{array}$ & $148.12 \pm 57.58$ & $\begin{array}{l}135.60 \pm \\
24.17\end{array}$ & $\begin{array}{l}120.54 \pm \\
24.55\end{array}$ & $109.72 \pm 15.30$ & $\begin{array}{l}\text { F } 251.833 \\
\text { P.000 }\end{array}$ \\
\hline $\begin{array}{l}\text { Fat } \\
\text { Mean } \pm \text { SD }\end{array}$ & $\begin{array}{l}53.21 \pm \\
6.73\end{array}$ & $\begin{array}{l}58.25 \pm \\
4.76\end{array}$ & $\begin{array}{l}29.82 \pm \\
7.03\end{array}$ & $\begin{array}{l}23.70 \pm \\
4.61\end{array}$ & $22.51 \pm 5.00$ & $21.03 \pm 0.95$ & $\begin{array}{l}\text { F 553.064 } \\
\text { P .000 }\end{array}$ \\
\hline
\end{tabular}

ANOVA Testlevel of significance $p=\leq 0.05$ 
Table (5): Mean and standard deviation of vitamins intake according to duration until complete burn wound healing

\begin{tabular}{|c|c|c|c|c|c|c|c|}
\hline \multirow[b]{2}{*}{ Vitamins } & \multicolumn{2}{|l|}{ Study group } & \multicolumn{4}{|l|}{ Control group } & \multirow{2}{*}{$\begin{array}{l}\text { Significa } \\
\text { nce level } \\
\text { ANOVA } \\
\text { Test }\end{array}$} \\
\hline & $\begin{array}{l}\text { at the end of } \\
\text { 2th week }\end{array}$ & $\begin{array}{l}\text { at the end } \\
\text { of } 3 \text { rd week }\end{array}$ & $\begin{array}{l}\text { at the end of } \\
\text { 3rd week }\end{array}$ & $\begin{array}{l}\text { at the end of } \\
\text { 4th week }\end{array}$ & $\begin{array}{l}\text { at the end } \\
\text { of } 5 \text { th week }\end{array}$ & $\begin{array}{l}\text { at the end of } \\
\text { 6th week }\end{array}$ & \\
\hline $\begin{array}{l}\text { B1Mean } \pm \\
\text { SD }\end{array}$ & $\begin{array}{l}1.021 \pm \\
.155\end{array}$ & $\begin{array}{l}1.107 \pm \\
.136\end{array}$ & $\begin{array}{l}.742 \pm \\
.368\end{array}$ & $\begin{array}{l}.640 \pm \\
.178\end{array}$ & $\begin{array}{l}.575 \pm \\
.118\end{array}$ & $\begin{array}{l}.531 \pm \\
.039\end{array}$ & $\begin{array}{l}\text { F } 134.648 \\
\text { P .000*** }\end{array}$ \\
\hline $\begin{array}{l}\text { B2Mean } \pm \\
\text { SD }\end{array}$ & $\begin{array}{l}1.360 \pm \\
.147\end{array}$ & $\begin{array}{l}1.403 \pm \\
.102\end{array}$ & $\begin{array}{l}.841 \pm \\
.186\end{array}$ & $\begin{array}{l}.749 \pm \\
.172\end{array}$ & $\begin{array}{l}.703 \pm \\
.177\end{array}$ & $\begin{array}{l}.584 \pm \\
.088\end{array}$ & $\begin{array}{l}\text { F325.708 } \\
\text { P.000*** }\end{array}$ \\
\hline $\begin{array}{l}\text { NiacinMea } \\
\mathbf{n} \pm \text { SD }\end{array}$ & $\begin{array}{l}70.413 \pm 7.52 \\
3\end{array}$ & $\begin{array}{l}71.319 \pm 3.78 \\
7\end{array}$ & $\begin{array}{l}55.448 \pm \\
23.529 \\
\end{array}$ & $\begin{array}{l}43.268 \pm \\
17.764 \\
\end{array}$ & $\begin{array}{l}44.366 \pm \\
22.020\end{array}$ & $42.675 \pm 9.834$ & $\begin{array}{l}\text { F } 73.533 \\
\text { P .000*** }\end{array}$ \\
\hline $\begin{array}{l}\text { AMean } \pm S \\
\text { D }\end{array}$ & $\begin{array}{l}878.404 \pm 90 . \\
684\end{array}$ & $\begin{array}{l}878.033 \pm 64 . \\
449\end{array}$ & $\begin{array}{l}332.524 \pm 122 \\
.363\end{array}$ & $\begin{array}{l}417.536 \pm 377 . \\
260\end{array}$ & $\begin{array}{l}282.351 \pm 10 \\
4.857\end{array}$ & $\begin{array}{l}242.567 \pm 30.09 \\
0\end{array}$ & $\begin{array}{l}\mathrm{F} 108.767 \\
\mathrm{P} .000^{* * * *}\end{array}$ \\
\hline $\begin{array}{l}\text { CMean } \pm S \\
\text { D }\end{array}$ & $\begin{array}{l}34.146 \pm 9.11 \\
9\end{array}$ & $\begin{array}{l}38.190 \pm 8.24 \\
8\end{array}$ & $\begin{array}{l}60.768 \pm \\
25.128\end{array}$ & $\begin{array}{l}47.076 \pm \\
18.072\end{array}$ & $\begin{array}{l}41.363 \pm \\
13.157\end{array}$ & $35.813 \pm 6.575$ & $\begin{array}{l}\text { F } 6.862 \\
\text { P .011** }\end{array}$ \\
\hline $\begin{array}{l}\text { B6Mean } \pm \\
\text { SD }\end{array}$ & $\begin{array}{l}1.195 \pm \\
.137\end{array}$ & $\begin{array}{l}1.264 \pm \\
.070\end{array}$ & $\begin{array}{l}.618 \pm \\
.334\end{array}$ & $\begin{array}{l}.508 \pm \\
.160\end{array}$ & $\begin{array}{l}.483 \pm \\
.178\end{array}$ & $\begin{array}{l}.477 \pm \\
.058\end{array}$ & $\begin{array}{l}\mathrm{F} 460.281 \\
\mathrm{P} .000^{* * * *}\end{array}$ \\
\hline
\end{tabular}

ANOVA Test level of significance $p=\leq 0.05$

Table (6): Mean and standard deviation of Minerals intake according to duration until complete burn wound healing

\begin{tabular}{|c|c|c|c|c|c|c|c|}
\hline \multirow[b]{2}{*}{ Minerals } & \multicolumn{2}{|l|}{ Study group } & \multicolumn{4}{|l|}{ Control } & \multirow{2}{*}{$\begin{array}{l}\text { Significance } \\
\text { level } \\
\text { ANOVA } \\
\text { Test }\end{array}$} \\
\hline & $\begin{array}{l}\text { at the end } \\
\text { of } 2 \text { th week }\end{array}$ & $\begin{array}{l}\text { at the end of } \\
\text { 3rd week }\end{array}$ & $\begin{array}{l}\text { at the end of } \\
\text { 3rd week }\end{array}$ & $\begin{array}{l}\text { at the end } \\
\text { of } 4 \text { th week }\end{array}$ & $\begin{array}{l}\text { at the end of } \\
5 \text { th week }\end{array}$ & $\begin{array}{l}\text { at the end of } \\
\text { 6th week }\end{array}$ & \\
\hline $\begin{array}{l}\text { NaMean } \pm S \\
\text { D }\end{array}$ & $\begin{array}{l}770.00 \pm \\
272.40\end{array}$ & $\begin{array}{l}909.93 \pm \\
234.81\end{array}$ & $\begin{array}{l}377.64 \pm \\
154.45\end{array}$ & $\begin{array}{l}350.09 \pm \\
72.26\end{array}$ & $\begin{array}{l}305.98 \pm \\
71.41\end{array}$ & $\begin{array}{l}298.64 \pm \\
48.30\end{array}$ & $\begin{array}{l}\text { F } 107.420 \\
\text { P .000*** }\end{array}$ \\
\hline $\begin{array}{l}\text { KMean } \pm \text { S } \\
\text { D }\end{array}$ & $\begin{array}{l}955.24 \pm 153 \\
79\end{array}$ & $\begin{array}{l}1021.26 \pm \\
138.90\end{array}$ & $\begin{array}{l}691.65 \pm \\
369.33\end{array}$ & $\begin{array}{l}756.17 \pm \\
177.32\end{array}$ & $\begin{array}{l}869.79 \pm \\
233.61\end{array}$ & $\begin{array}{l}775.63 \pm \\
91.25\end{array}$ & $\begin{array}{l}\text { F24.882 } \\
\text { P.000*** }\end{array}$ \\
\hline $\begin{array}{l}\text { CaMean } \pm S \\
\text { D }\end{array}$ & $\begin{array}{l}1039.93 \pm 12 \\
2.01\end{array}$ & $\begin{array}{l}1059.83 \pm \\
105.52\end{array}$ & $\begin{array}{l}426.74 \pm 167 . \\
12\end{array}$ & $\begin{array}{l}413.26 \pm 100 \\
22\end{array}$ & $338.38 \pm 53.46$ & $\begin{array}{l}352.44 \pm 50.9 \\
5\end{array}$ & $\begin{array}{l}\mathrm{F} 68.423 \\
\mathrm{P} .000^{* * *}\end{array}$ \\
\hline $\begin{array}{l}\text { MgMean } \pm \\
\text { SD }\end{array}$ & $\begin{array}{l}99.24 \pm \\
14.62\end{array}$ & $105.59 \pm 14.92$ & $\begin{array}{l}69.99 \pm \\
35.84\end{array}$ & $\begin{array}{l}73.77 \pm \\
17.03\end{array}$ & $\begin{array}{l}83.60 \pm \\
21.55 \\
\end{array}$ & $\begin{array}{l}75.29 \pm \\
7.63\end{array}$ & $\begin{array}{l}\mathrm{F} 44.196 \\
\text { P } .000 * * *\end{array}$ \\
\hline $\begin{array}{l}\text { FeMean } \pm \text { S } \\
\text { D }\end{array}$ & $\begin{array}{l}11.37 \pm \\
1.41\end{array}$ & $\begin{array}{l}12.08 \pm \\
1.20\end{array}$ & $\begin{array}{l}7.42 \pm \\
0.64\end{array}$ & $\begin{array}{l}6.42 \pm \\
1.71\end{array}$ & $\begin{array}{l}6.15 \pm \\
1.45\end{array}$ & $\begin{array}{l}5.18 \pm \\
0.75\end{array}$ & $\begin{array}{l}\text { F } 241.852 \\
\text { P .000**** }\end{array}$ \\
\hline $\begin{array}{l}\text { ZnMean } \pm \text { S } \\
\text { D }\end{array}$ & $5.72 \pm 0.79$ & $5.98 \pm 0.87$ & $3.25 \pm 1.99$ & $3.28 \pm 0.80$ & $3.75 \pm 1.07$ & $3.40 \pm 0.39$ & $\begin{array}{l}\text { F } 143.652 \\
\text { P .000*** }\end{array}$ \\
\hline $\begin{array}{l}\text { CuMean } \pm S \\
\text { D }\end{array}$ & $\begin{array}{l}0.60 \pm \\
0.07\end{array}$ & $\begin{array}{l}0.60 \pm \\
0.06\end{array}$ & $\begin{array}{l}0.33 \pm \\
0.08\end{array}$ & $\begin{array}{l}0.27 \pm \\
0.08\end{array}$ & $\begin{array}{l}0.24 \pm \\
0.08\end{array}$ & $\begin{array}{l}0.22 \pm \\
0.03\end{array}$ & $\begin{array}{l}\text { F 399.536 } \\
\text { P 0.000*** }\end{array}$ \\
\hline $\begin{array}{l}\mathbf{P} \\
\text { Mean } \pm \text { SD }\end{array}$ & $\begin{array}{l}1305.94 \pm 14 \\
9.31\end{array}$ & $\begin{array}{l}1361.23 \pm 117.8 \\
8\end{array}$ & $\begin{array}{l}636.02 \pm 72.7 \\
1\end{array}$ & $\begin{array}{l}517.91 \pm 91.4 \\
6\end{array}$ & $\begin{array}{l}499.30 \pm 126.7 \\
0\end{array}$ & $\begin{array}{l}420.33 \pm 49.0 \\
4\end{array}$ & $\begin{array}{l}\text { F 770.255 } \\
\text { P 0.000*** }\end{array}$ \\
\hline
\end{tabular}

ANOVA Test level of significance $p=\leq 0.05$

Table (7): Distribution of bacteriological wound culture among study and control group

\begin{tabular}{|c|c|c|c|c|c|c|c|}
\hline & & & \multicolumn{2}{|c|}{$\begin{array}{l}\text { Study group } \\
\mathrm{No}=(33)\end{array}$} & \multicolumn{2}{|c|}{$\begin{array}{l}\text { Control group } \\
\mathrm{No}=(33)\end{array}$} & \multirow[t]{2}{*}{$\begin{array}{l}\text { Level of } \\
\text { significance }\end{array}$} \\
\hline & & & $\mathrm{No}$ & $\%$ & No & $\%$ & \\
\hline \multirow{4}{*}{$\begin{array}{l}\text { bacteriological } \\
\text { wound culture } \\
\text { 1st week }\end{array}$} & negative & & 27 & $81.8 \%$ & 15 & $45.5 \%$ & \multirow{4}{*}{$\begin{array}{l}9.095 \\
\mathrm{P}=0.021 *\end{array}$} \\
\hline & \multirow[t]{3}{*}{ positive } & staph & 4 & $12.12 \%$ & 11 & $33.33 \%$ & \\
\hline & & strepto & 1 & $3.03 \%$ & 5 & $15.15 \%$ & \\
\hline & & pseudomonous & 1 & $3.03 \%$ & 2 & $6.06 \%$ & \\
\hline \multirow{4}{*}{$\begin{array}{l}\text { bacteriological } \\
\text { wound culture } \\
\text { 2ndweek }\end{array}$} & negative & & 25 & $75.8 \%$ & 5 & $15.2 \%$ & \multirow{4}{*}{$\begin{array}{l}24.619 \\
\mathrm{P}=0.000 * * *\end{array}$} \\
\hline & \multirow[t]{3}{*}{ positive } & staph & 5 & $15.15 \%$ & 20 & $60.60 \%$ & \\
\hline & & strepto & 2 & $6.06 \%$ & 5 & $15.15 \%$ & \\
\hline & & pseudomonous & 1 & $3.03 \%$ & 3 & $9.09 \%$ & \\
\hline & & & \multicolumn{2}{|c|}{$\mathrm{No}=(20)$} & \multicolumn{2}{|c|}{$\mathrm{No}=(33)$} & \\
\hline \multirow{4}{*}{$\begin{array}{l}\text { bacteriological } \\
\text { wound culture } \\
\text { 3rd week }\end{array}$} & negative & & 20 & $100.0 \%$ & 4 & $12.1 \%$ & \multirow{4}{*}{$\begin{array}{l}30.813 \\
\mathrm{P}=0.000 * * *\end{array}$} \\
\hline & \multirow[t]{3}{*}{ positive } & staph & & & 20 & $60.60 \%$ & \\
\hline & & strepto & & & 6 & $18.18 \%$ & \\
\hline & & pseudomonous & & & 3 & $9.09 \%$ & \\
\hline & & & \multicolumn{2}{|c|}{$\mathrm{No}=(0)$} & \multicolumn{2}{|c|}{$\mathrm{No}=(30)$} & \\
\hline \multirow{4}{*}{$\begin{array}{l}\text { bacteriological } \\
\text { wound culture } \\
\text { 4th week }\end{array}$} & negative & & 0 & $0.0 \%$ & 20 & $66.66 \%$ & \\
\hline & \multirow[t]{3}{*}{ positive } & staph & & & 6 & $20 \%$ & \\
\hline & & strepto & & & 2 & $6.66 \%$ & \\
\hline & & pseudomonous & & & 2 & $6.66 \%$ & \\
\hline & & & \multicolumn{2}{|c|}{$\mathrm{No}=(0)$} & \multicolumn{2}{|c|}{$\mathrm{No}=(17)$} & \\
\hline \multirow{2}{*}{$\begin{array}{l}\text { bacteriological } \\
\text { wound culture } \\
5 \text { th week }\end{array}$} & negative & & 0 & $0.0 \%$ & 16 & $94.1 \%$ & \\
\hline & positive & staph & 0 & $0.0 \%$ & 1 & $5.9 \%$ & \\
\hline
\end{tabular}




\begin{tabular}{|l|l|l|l|l|l|l|l|}
\hline \multicolumn{2}{|c|}{} & & \multicolumn{2}{l|}{$\mathrm{No}=(0)$} & \multicolumn{2}{l|}{$\mathrm{No}=(8)$} & \\
\hline $\begin{array}{l}\text { bacteriological } \\
\text { wound culture } \\
\text { 6th week }\end{array}$ & negative & & 0 & $0.0 \%$ & 8 & $100.0 \%$ & \\
\cline { 2 - 8 } & positive & & 0 & $0.0 \%$ & 0 & $0.0 \%$ & \\
\hline
\end{tabular}

Level of significance $p=\leq 0.05$

Table (8): Correlation between Hemoglobin and Macro and Micronutrients intake among study and control group.

\begin{tabular}{|c|c|c|c|c|}
\hline \multirow{2}{*}{$\begin{array}{l}\text { Nutrients } \\
\text { intake }\end{array}$} & \multicolumn{2}{|l|}{ Study group } & \multicolumn{2}{|c|}{ Control group } \\
\hline & $\begin{array}{l}\text { Pearson } \\
\text { Correlation }\end{array}$ & Sig. & $\begin{array}{l}\text { Pearson } \\
\text { Correlation }\end{array}$ & Sig. \\
\hline Caloric & .121 & .501 & .028 & .876 \\
\hline Protein animal & -.412 & $.017 *$ & -.068 & .708 \\
\hline Protein plant & .132 & .465 & .167 & .352 \\
\hline Protein & -.158 & .380 & .041 & .822 \\
\hline Lipid animal & -.401 & $.021^{*}$ & -.069 & .702 \\
\hline Lipid plant & -.067 & .711 & .279 & .116 \\
\hline Fat & -.235 & .187 & .077 & .672 \\
\hline Carbohydrate & .150 & .404 & .169 & .346 \\
\hline $\mathrm{Na}$ & .132 & .465 & -.113 & .533 \\
\hline $\mathrm{K}$ & .047 & .796 & .098 & .589 \\
\hline $\mathrm{Ca}$ & -.040 & .824 & .029 & .871 \\
\hline $\mathrm{Mg}$ & .102 & .573 & .115 & .524 \\
\hline $\mathrm{Fe}$ & .027 & .881 & -.151 & .401 \\
\hline $\mathrm{Zn}$ & .096 & .596 & .067 & .713 \\
\hline $\mathrm{Cu}$ & -.216 & .228 & -.185 & .302 \\
\hline $\mathrm{P}$ & -.016 & .931 & -.069 & .703 \\
\hline Iron animal & -.391 & $.024 *$ & -.072 & .689 \\
\hline Iron plant & .094 & .602 & -.074 & .683 \\
\hline B1 & .088 & .627 & .080 & .657 \\
\hline B2 & -.055 & .760 & .025 & .889 \\
\hline Niacin & -.376 & $.031^{*}$ & -.097 & .592 \\
\hline $\mathrm{A}$ & -.143 & .426 & -.152 & .398 \\
\hline $\mathrm{C}$ & .039 & .831 & -.131 & .469 \\
\hline B6 & -.069 & .701 & -.273 & .124 \\
\hline
\end{tabular}

Pearson Correlationtest level of significance $p=\leq 0.05$

Table (9):Correlation between Albumin and Macro and Micronutrients intake among study and control group.

\begin{tabular}{|c|c|c|c|c|}
\hline \multirow{2}{*}{$\begin{array}{l}\text { Nutrients } \\
\text { intake }\end{array}$} & \multicolumn{2}{|l|}{ Study group } & \multicolumn{2}{|c|}{ Control group } \\
\hline & $\begin{array}{l}\text { Pearson } \\
\text { Correlation }\end{array}$ & Sig. & $\begin{array}{l}\text { Pearson } \\
\text { Correlation }\end{array}$ & Sig. \\
\hline Caloric & .020 & .913 & -.260 & .144 \\
\hline Protein animal & -.159 & .377 & .178 & .323 \\
\hline Protein plant & -.353 & $.044^{*}$ & .065 & .721 \\
\hline Protein & -.255 & .152 & .109 & .547 \\
\hline Lipid animal & .176 & .328 & -.110 & .543 \\
\hline Lipid plant & .064 & .723 & -.144 & .424 \\
\hline Fat & .111 & .538 & -.200 & .265 \\
\hline Carbohydrate & -.031 & .863 & -.246 & .168 \\
\hline $\mathrm{Na}$ & .084 & .644 & -.154 & .394 \\
\hline $\mathrm{K}$ & -.030 & .870 & .013 & .945 \\
\hline $\mathrm{Ca}$ & -.007 & .967 & -.196 & .274 \\
\hline $\mathrm{Mg}$ & .020 & .913 & -.022 & .904 \\
\hline $\mathrm{Fe}$ & .041 & .820 & -.260 & .144 \\
\hline $\mathrm{Zn}$ & .048 & .791 & -.026 & .884 \\
\hline $\mathrm{Cu}$ & -.115 & .523 & -.312 & .077 \\
\hline $\mathrm{P}$ & .043 & .813 & -.252 & .157 \\
\hline Iron animal & .183 & .308 & -.128 & .479 \\
\hline Iron plant & -.026 & .885 & -.281 & .113 \\
\hline B1 & .036 & .844 & -.304 & .086 \\
\hline B2 & .015 & .933 & -.304 & .085 \\
\hline Niacin & .252 & .156 & -.120 & .506 \\
\hline $\mathrm{A}$ & -.065 & .720 & -.368 & $.035 *$ \\
\hline $\mathrm{C}$ & -.106 & .557 & -.154 & .391 \\
\hline B6 & .093 & .608 & -.167 & .354 \\
\hline
\end{tabular}

Pearson Correlation test level of significance $p=\leq 0.05$ 
Table (10): Correlation between total Protein and Macro and Micronutrients among study and control group

\begin{tabular}{|c|c|c|c|c|}
\hline \multirow{2}{*}{$\begin{array}{l}\text { Nutrients } \\
\text { intake }\end{array}$} & \multicolumn{2}{|l|}{ Study group } & \multicolumn{2}{|c|}{ Control group } \\
\hline & $\begin{array}{l}\text { Pearson } \\
\text { Correlation }\end{array}$ & Sig. & $\begin{array}{l}\text { Pearson } \\
\text { Correlation }\end{array}$ & Sig. \\
\hline Caloric & .025 & .889 & -.293 & .098 \\
\hline Protein animal & -.111 & .540 & .190 & .291 \\
\hline Protein plant & -.353 & $.044 *$ & .014 & .940 \\
\hline Protein & -.235 & .189 & .167 & .353 \\
\hline Lipid animal & -.046 & .798 & .187 & .298 \\
\hline Lipid plant & -.410 & .018 & -.131 & .466 \\
\hline Fat & -.258 & .148 & .125 & .489 \\
\hline Carbohydrate & -.047 & .796 & -.277 & .118 \\
\hline $\mathrm{Na}$ & .048 & .790 & -.226 & .206 \\
\hline $\mathrm{K}$ & -.027 & .880 & .272 & .126 \\
\hline $\mathrm{Ca}$ & .107 & .554 & -.440 & $.010^{*}$ \\
\hline $\mathrm{Mg}$ & -.010 & .957 & .236 & .187 \\
\hline $\mathrm{Fe}$ & .069 & .704 & -.162 & .369 \\
\hline $\mathrm{Zn}$ & .026 & .886 & .278 & .117 \\
\hline $\mathrm{Cu}$ & .112 & .534 & -.238 & .183 \\
\hline $\mathrm{P}$ & .149 & .407 & -.257 & .149 \\
\hline Iron animal & .193 & .281 & -.064 & .724 \\
\hline Iron plant & -.035 & .849 & -.329 & .061 \\
\hline B1 & .027 & .880 & -.228 & .201 \\
\hline B2 & .148 & .410 & -.199 & .267 \\
\hline Niacin & .287 & .105 & .027 & .880 \\
\hline $\mathrm{A}$ & .165 & .359 & -.248 & .164 \\
\hline $\mathrm{C}$ & -.101 & .577 & -.135 & .454 \\
\hline B6 & .237 & .184 & -.066 & .713 \\
\hline
\end{tabular}

Pearson Correlation test level of significance $\mathrm{p}=\leq 0.05$

\section{References}

[1]. World Health Organization. Violence and injury prevention and disability (VIP) 2011. Available at: www.who.int/ violence injury privation injury/ burns. Retrieved on 4/10/2011. 8-Chaudhary I.

[2]. Burns frequency and mortality related to various age groups. Journal of surgery Pakistan (international), 2009; 14(2):67-71.

[3]. Gawkrodger D. Dermatology, An Illustrated Colour Text. 3rd ed. Edinburgh: Churchill Livingstone; 2002.

[4]. Munster A. Burns of the world. Journal of Burn Care Rehabilitation 1996; 17: 477-484.

[5]. Rosdahle C, Kowalski M. Textbook of basic nursing. 8th ed. Philadelphia: Lippincott Williams \& Wilkins, 2003.

[6]. Scott J, Muangman P, Tamura R, Zhu K, Liang Z, Anthony J . Substance P levels and neutral endopeptidase activity in acute burn wounds and hypertrophic scar. Plastic Reconstructive Surgery. 2005; 115: 1095-1102.

[7]. Hettiaratchy S, Papini R. ABC of burns: Initial management of a major burn: II - assessment and resuscitation. British Medical Journal. 2004; 329: 101-103

[8]. Singer A, Berruti L, Thode H, McClain S. Standardized burn model using a multiparametric histologic analysis of burn depth. Academic Emergency Medicine 2000;7:1-6.

[9]. Practice nursing care for clients with Burns. Available at: http://intranet. tdmu.edu.ua/ data/kafedra/i nternal/klinpat/classes_ stud/en/nurse/rnbsn\%20\%282\%20year\%20program\%29/full\%20time\%20study/professional\%20nursing\%20role\%20transition\%20 practicum $/ 1 / 41 . \% 20 \mathrm{Pr} \% 20$ nur\%20care\%20for\%20c1\%20with\%20Burns.htm

[10]. Hart D, Wolf S, Chinkes D, Gore D. Determinants of skeletal muscle catabolism after severe burn. Annals of Surgery 2000; 455465.

[11]. Yu YM, Tompkins R, Ryan C, Young V. The metabolic basis of the increase of the increase in energy expenditure in severely burned patients. Journal of Parenteral Enteral Nutrition 1999; 23(3):160-168. [PubMed: 10338224]

[12]. Rutan R, Herndon D. Growth delay in postburn pediatric patients. Arch Surgery. Mar; 1990 125(3):392-395. [PubMed: 2306187]

[13]. Lee J, Herndon D. Modulation of the post-burn hypermetabolic state. Nestlé Nutrition Workshop Series: Clinical and Performance Program. 2003; 8:39-49.

[14]. Barrow R, Hawkins H, Aarsland A. Identification of factors contributing to hepatomegaly in severely burned children. Shock. 2005; 24(6):523-528. [PubMed: 16317382]

[15]. Barrow R, Wolfe R, Dasu M. The use of beta-adrenergic blockade in preventing traumainduced hepatomegaly. Annals of Surgery 2006; 243(1):115-120. [PubMed: 16371745]

[16]. Herndon D, Hart D, Wolf S. Reversal of catabolism by beta-blockade after severe burns. New England Journal of Medicine 2001; 345(17):1223-1229. [PubMed: 11680441]

[17]. Chang DW, DeSantiL,Demling RH. Anticatabolic and anabolic strategies in critical illness: a review of current treatment modalities. Shock 1998;10(3):155-60

[18]. Shakespeare P. Burn wound healing and skin substitutes. Burns 2001; 27: 517-522.

[19]. Morison M. Clinical skills series: A color guide to the nursing management of wound. Netherland: Wolf Publishing Ltd. 1992.

[20]. Chambers N. wound management in: Hugston R, Simpson P. Fundamentals of nursing practice. London: MacMillan Company, $1999 ; 145-262$.

[21]. Cioffi W, Vaughan G, Heironimus J, Jordan B, Mason A, Pruitt B. Dissociation of blood volume and flow in regulation of salt and water balance in burn patients. Annual of Surgery 2000; 214:213-20.

[22]. Bayyumi H. Comperative study between two nutritional regimens on wound healing of moderate degree patients. Alexandria scientific nursing journal 2008; 7.

[23]. Tancheva D, Arabadziev J, Gergov G, Lachev N, Todorova S ,Hristova A. Comparison of estimated energy requirements in severely burned patients with measurements by using indirect calorimetry. Euro-Mediterranean Council for Burns and Fire Disasters (MBC) 2005; 18(1): 16-18. 
[24]. Ahmed W. Effect of nutritional regimen among moderately burn patients on graft take. Unpublished doctor thesis, Higher institute of nursing. Faculty of Nursing. Alexandria University, 2003.

[25]. MacKay D, Miller A. Nutritional support for wound healing. Alternative Medicine Review. 2003;8(2):359-77

[26]. Rousseau AF, Losser M R, IchaiC , Berger M M. ESPEN endorsed recommendations: Nutritional therapy in major burns, Clinical Nutrition 2013; 32(4): 497-502. Available at: www.espen.info/wp/wordpress/wp-content/uploads/2013/06/burns.pdf.

[27]. Machado M, Gragnani A, Ferreira L. Burns, metabolism and nutritional Requirements, Nutrition Of Hospital 2011; 26(4):692-700

[28]. Prins, A. Nutritional management of the burn patient. South African Journal of Clinical Nutrition 2009;22(1): 9-15

[29]. SahibA, Al-Jawad F. Effect of antioxidants micronutrients on the incidence of wound infection in burn patients. Annals of Burns and Fires Disaster 2010; 23 (4):199-205.

[30]. Curreri PW, Richmond D, Marvin J, Baxter CR. Dietary requirements of patients with major burnsJournal of the American Dietetic Association 1974; 65: 415-7.

[31]. Wilmore D, Curreri P, Spitzer K. Supranormal dietary intake in thermally injured hypermetabolic patients. Surgery, Gynecology \& Obstetrics. 1971; 132(5):881-6. [PubMed: 4995336]

[32]. Hemeda O, El-sayed N, Mahmoud F, Abd El-wahab M. Assessment of the nutritional care of the critically ill patients in the intensive care units of federal hospital in United Arab Emirates. Master thesis. , Higher institute of public health. Alexandria University, 2009:44-86.

[33]. Berger M, Eggimann P, Heyland D. Reduction of nosocomial pneumonia after major burns by trace element supplementation: aggregation of two randomised trials. Critical Care 2006;10(6): 153. doi:10.1186/cc5084.

[34]. Bolarinwa A, Oyebola D, Akindeinde G: Effect of malnutrition on basal and induced gastric acid secretion. Nigerian journal of physiological sciences 1991; 5(2): 144-148.

[35]. Berger M, Eggimann P, Heyland D. Reduction of nosocomial pneumonia after major burns by trace element supplementation: aggregation of two randomised trials. Critical Care 2006;10(6): 153. doi:10.1186/cc5084.

[36]. Dabone C, Delisle H, ReceveurO. Poor Nutritional Status Of School Children in Urban and Peri-Urban Areas of Ouagadougou (Burkina Faso). Nutrition Journal 2011; 10: 34.

[37]. Gibran N. Heimbach D. Current status of burn wound pathophysiology. Clinical Plastic Surgery. 2000; 27:11-22

[38]. Castaneda C, Charnley J, Evans W, Crim M. Elderly women accommodate to a low-protein diet with losses of body cell mass, muscle function, and immune response. American Journal of Clinical Nutrition 1995; 62:30 -9.

[39]. Amir O, Liu A, Chang A. Stratification of highest-risk patients with chronic skin ulcers in a Stanford retrospective cohort includes diabetes, need for systemic antibiotics, and albumin levels. Ulcers 2012; 72:1-7.

[40]. Vanek V. The use of serum albumin as a prognostic or nutritional marker and the pros and cons of IV albumin therapy. Nutrition in Clinical Practice 1998; 13: 110-21

[41]. Lee S, Posthauer E, Dorner B, Redovian V, Maloney M. Pressure ulcer healing with a concentrated, fortified, collagen protein hydrolysate supplement: A randomized controlled trial. Advances in Skin \& Wound Care 2006; 19(2): 92-96.

[42]. A'Beckett K, Baytieh L, Carr-Thompson A, Fox V, MacLennan P, Marriott J, Nicholls C, Petrunoff N. Clinical Practice Guidelines, Nutrition Burn Patient Management. New South Wales, Statewide Burn Injury Service 2011: 56 - 59

[43]. Williams J, Barbul A. Nutrition and wound healing. Surgery Of Clinical North America 2003; 83(3):571-596

[44]. Aryee E, Wiredu E, Asante M, Asare G, Adjei D. Energy and Nutrient intake of Burns Patients in Selected Hospitals in Ghana. Master of Philosophy is an advanced postgraduate research degree, University of Ghana, 2011.

[45]. Lee J, Gauglitz G. , Herndon G, Hal K, Hawkins H, Halder S, Jeschke M. Association between dietary fat content and outcomes in pediatric burn patients, Surgery Of Research 2011; 166(1) doi:10.1016/j.jss.2010.10.006.

[46]. Erridge C, Attina T, Corinne M, Spickett C, Webb D . A high-fat meal induces low-grade endotoxemia: evidence of a novel mechanism of postprandial inflammation, American Journal of Clinical Nutrition 2007; 86(5): 1286 - 92.

[47]. Masters B, Aarabi S, Sidhwa F, Wood F. High-carbohydrate, high- protein, low fat versus low-carbohydrate, high-protein, high-fat enteral feeds for burns. Cochrane Database of Systematic Reviews 2012; 1. Art. No:. CD006122. DOI: 10.1002/ 14651858.CD006122.pub3

[48]. Williams F, Herndon D, Kulp G. Propranolol decreases cardiac work in a dose-dependent manner in severely burned children. Surgery. 2010 [PMC free article] [PubMed]

[49]. Peng X, Yan H, You Z, Wang P, Wang S. Clinical and protein metabolic efficacy of glutamine granules-supplemented enteral nutrition in severely burned patients. Burns 2005; 31: 342-6.

[50]. Young V, Castillo L. Plasma arginine and leucine kinetics and urea production rates in burn patients. Metabolism 1995; 44:659666. [PubMed: 7752916]

[51]. Ryan C, Burke J. Relations among arginine, citrulline, ornithine, and leucine kinetics in adult burn patients. American Journal Of Clinical Nutrition 1995; 62:960-968. [PubMed: 7572742]

[52]. Adams M, Lombi E, Zhao F, McGrath S. Evidence of low selenium concentrations in UK bread-making wheat grain. Journal of the Science of Food and Agriculture 2002; 82: 1160-1165.

[53]. Shewry P. The HEALTHGRAIN programme opens new opportunities for improving wheat for nutrition and health. Nutrition Bulletin 2009, 34(2): 225-231.

[54]. Fraley R. Improving the nutritional quality of plants. In: Vasil IK (ed) Plant biotechnology and beyond Kluwer, Dordrecht 2003: 61-67.

[55]. Shewry P, Powers S, Field J, Fido R, Jones H, Arnold G, West J, Lazzeri P, Barcelo P, Barro F, Tatham A, Bekes F, Butow B, Darlington H. Comparative field performance over three years and two sites of transgenic wheat lines expressing HMW subunit transgenes. Theoretical and Applied Genetics 2006; 113: 128-136.

[56]. Topping D. Cereal complex carbohydrates and their contribution to human health. Journal of Cereal Science 2007; 46: 220-229

[57]. Hadjivassiliou M, Grunewald R, Sharrack B, Sanders D, Lobo A, Williamson C, Woodroofe N, Wood N, Davies-Jones A. Gluten ataxia in perspective: epidemiology, genetic susceptibility and clinical characteristics. Brain 2003; 126: 685-691.

[58]. Caso G, Feiner J, Mileva I. Response of albumin synthesis to oral nutrients in young and elderly subjects. American Journal Of Clinical Nutrition 2007;85:446-451.

[59]. Cayol M, Boirie Y, Prugnaud J, Gachon P, Beaufrere B, Obled C. Precursor pool for hepatic protein synthesis in humans: effects of tracer route infusion and dietary proteins. American Journal Of Physiolophy 1996; 270: 980-987.

[60]. Cayol M, Boirie Y, Rambourdin F. Influence of protein intake on whole body and splanchnic leucine kinetics in humans. American Journal of Physiolophy 1997;272:584-591.

[61]. Naber T, Bree A, Schermer T. Specificity of indexes of malnutrition when applied to apparently healthy people: the effect of age. American Journal Of Clinical Nutrition 1997;65:1721-5. 
[62]. World Health Organisation. Worldwide Prevalence of Anemia 1993-2005. WHO Global Database on Anemia. Centers for Disease Control and Prevention. Atlanta, Georgia, 2005

[63]. Martínez C, López G, Ros G, Vidal M, Abellán P. Use of heme iron concentrate in the fortification of weaning foods. J Journal of Agricultural and Food Chemistry 2000; 48: 2930-2936.

[64]. Al-Jawad F, Sahib A, Ahmed H, Alkaisy A. Effect of N- acetylcysteine on wound healing in Burned patients Mustansiriya Medical Journal 2011; $10(1): 28-31$.

[65]. Berger M, Spertini F, Shenkin A, Wardle C, Wiesner C, Schindler C. Trace element supplementation modulates pulmonary infection rates after major burns: a double-blind, placebo-controlled trial. American Journal Of Clinical Nutrition 2007;68(1):36571

[66]. Kurmis R, Aromataris E, Greenwood J.. The effectiveness of trace element supplementation following severe burn injury: A systematic review protocol, Joanna Briggs Institute: Database if Systematic Reviews \& implementation Reports2013; 11(11): 44 53.

[67]. Barbosa E, Faintuch J, Machado A, Goncalves V, Lopes M, Martins Fagundes R . Supplementation of vitamin E, vitamin C, and zinc attenuates oxidative stress in burned children: a randomized,double-blind, placebo-controlled pilot study. Journal Of Burn Care Research 2009;30:859-66.

[68]. Barbosa E, Faintuch J, Machado A, Goncalves V, Lopes M, Martins Fagundes R. Supplementation of vitamin E, vitamin C, and zinc attenuates oxidative stress in burned children: a randomized,double-blind, placebo-controlled pilot study. Journal Of Burn Care Research 2009;30:859-66.

[69]. Noori S. An overview of oxidative stress and anti-oxidant defence system, Open access scientific reports 2012; 1(8) doi10.4172/scientific reports, 413

[70]. Rojas A, Phillips T. Patients with chronic leg ulcers show diminished levels of vitamins A and E, carotenes, and zinc. Dermatologic Surgery Journal 1999; 25(8):601-604. [PubMed: 10491041]

[71]. Dorner B, Posthauer M, Thomas D. The role of nutrition in pressure ulcer prevention and treatment: National Pressure Ulcer Advisory Panel White Paper 2009. www.npuap.org

[72]. Kohn S, Kohn D, Schiller D. Effect of zinc supplementation on epidermal Langerhans' cells of elderly patients with decubital ulcers. Journal Of Dermatologic 2000; 27:258-263.

[73]. Cario E, Jung S, Harder D'Heureuse J. Effects of exogenous zinc supplementation on intestinal epithelial repair in vitro. European Journal of Clinical Investigation 2000; 30:419-428

[74]. Voelker,R. Copper and cancer. Journal of the American Medical Association 2000; 283:994.

[75]. Borkow G. Copper as Biocidal - Review of the Literature. Cupron Inc. 2004

[76]. Tenaud I, Sainte-Marie O, Jumbou P, Dreno. In vitro modulation of keratinocyte wound healing integrins by zinc, copper and manganese. British Journal of Dermatology 1999; 140:26-34.

[77]. Trumbo P, Yates A, Schlicker S, Poos M. Dietary reference intakes: vitamin A, vitamin K, arsenic, boron, chromium, copper, iodine, iron, manganese, molybdenum, nickel, silicon, vanadium, and zinc. Journal of the American Dietetic Association 2001; 101: 294-301.

[78]. Todorovic V. Food and wounds: nutritional factors in wound formation and healing. Wound Care 2002:43-54

[79]. Kapur D, Sharma S, Agarwal K. Effectiveness of Nutrition Education, Iron Supplementation or both on Iron Status in Children. Indian Pediatrics. 2003; 40: 1131-1144.

[80]. Saffle J, Graves C. Nutritional Support of the Burned Patient in: Herndon, D. Total Burn Care (3rd Ed.) Saunders Elsevier, 2007.

[81]. McClave S, Heyland D. The Physiologic Response and Associated Clinical Benefits From Provision of Early Enteral Nutrition. Nutrition in Clinical Practice 2009; 24(3):305-315. doi:10.1177/0884533609335176.

[82]. Bailey N, Clark M, Nordlund M, Shelton M, Farver K. New paradigm in nutrition support: using evidence to drive practice. Critical Care Nursing Quarterly 2012; 35(3):255-267. doi:10.1097/CNQ.0b013e3182542e30.

[83]. Woo S, Finch C, Broyles J, Wan J, Boswell R, Hurdle A. Early vs delayed enteral nutrition in critically ill medical patients. Nutrition in Clinical Practice Offer Publication of American Society Of Parenteral Enteral Nutrition 2010; 25(2):205-211. doi:10.1177/0884533610361605.

[84]. Mosier M, Pham T, Klein M. Early Enteral Nutrition in Burns: Compliance With Guidelines and Associated Outcomes in a Multicenter Study: Journal Of Burn Care Research 2011; 32(1):104-109. doi:10.1097/BCR.0b013e318204b3be.

[85]. Rimdeika R, Gudaviciene D, Adamonis K, Barauskas G, Pavalkis D, Endzinas Z. The effectiveness of caloric value of enteral nutrition in patients with major burns. Burns 2006; 32(1):83-6. doi: 10.1016/j.burns.2005.08.003. [PubMed: 16386376]

[86]. Suri M, Dhingra V, Raibagkar S, Mehta D. Nutrition in burns: need for an aggressive dynamic approach. Burns 2006; $32(7): 880-4$. doi: 10.1016/j.burns.2006.02.006. [PubMed: 16949211]

[87]. Khorasani E, Mansouri F. Effect of early enteral nutrition on morbidity and mortality in children with burns. Burns 2010; 36(7):1067-71. doi: 10.1016/j.burns 2009;12.005. [PubMed: 20403667]

[88]. Byrd - Bredbenner C, Moe G, Beshgetoor D, Berning J. Perspectives in Nutrition, McGraw-Hill Education $2013: 552$-559

[89]. Hart D, Wolf S, Chinkes D. Effects of early excision and aggressive enteral feeding on hypermetabolism, catabolism, and sepsis after severe burn. Journal of Trauma 2003; 54: 755-761.

[90]. Ragab N. Effectiveness of two dressing technique on the healing of recent moderately burned wound. Unpublished MD thesis, Alexandria University, Faculty of Nursing, 2002.

[91]. Minard G, Kudsk K, Melton S, Patton J, Tolley E. Early versus delayed feeding with an immune-enhancing diet in patients with severe head injuries. Journal Of Parenteral Enteral Nutrition 2000; 24(3):145-149. doi:10.1177/0148607100024003145.

[92]. Dvorak M, Noonan V, Bélanger L. Early versus late enteral feeding in patients with acute cervical spinal cord injury: a pilot study. Spine 2004; 29(9):E175-180.

[93]. Mogford J, Tawil N, Chen A, Gies D, Xia Y, Mustoe T . Effect of age and hypoxia on TGF beta1 receptor expression and signal transduction in human dermal fibroblasts: impact on cell migration. Journal of Cellular Physiology 2002;190: 259-265

[94]. World Health Organisation. Worldwide Prevalence of Anemia 1993-2005. WHO Global Database on Anemia. Centers for Disease Control and Prevention. Atlanta, Georgia, 2005

[95]. Chernoff R. Protein and older adults. Journal of the American College of Nutrition 2004;23:627S-630

[96]. Dorner B, Posthauer M, Thomas D; National Pressure Ulcer Advisory Panel. The role of nutrition in pressure ulcer prevention and treatment: National Pressure Ulcer Advisory Panel white paper. Advances in Skin and Wound Care 2012; 22(5):212-221

[97]. Thompson C, Fuhrman M. Nutrients and wound healing: still searching for the magic bullet. Nutrition in Clinical Practices 2005; 20(3):331-347.

[98]. Harrington L. Nutrition in critically ill adults: key processes and outcomes. Critical Care Nursing Clinics of North America 2004; 16: 459-65.

[99]. Wolfe R, Martini W. Changes in intermediary metabolism in several surgical illnesses. World Journal of Surgery 2000; 24 : 639-47.

[100]. Chan M, Chan G. Nutritional therapy for burns in children and adults. Nutrition 2008; 25: 261-269. 